\title{
Egy kevésbé ismert katonai attasé: NÉMETH Dezső vezérkari ezredes
}

Jómagam 1993-1998 között a Magyar Köztársaság moszkvai nagykövetségéhez beosztott katonai és légügyi attaséként teljesítettem szolgálatot az Oroszországi Föderációban. Akkor érlelődött meg bennem az elhatározás, hogy felkutatom elődeimet és megpróbálom bemutatni pályafutásukat. Így találtam rá egyik egykori elődöm, NÉMETH Dezső vezérkari ezredes nem mindennapi történetére.

„A második világháborús magyar katonai elitnek, illetve a tisztikarnak a pályafutása 1945-ben, de legkésőbb 1949-ben — kevés kivételtől eltekintve — derékba tört.... A koalíciós időszak politikai küzdelmeinek egyik színtere a hadsereg volt, amelyet rövid idő alatt »megtisztítottak« a régi, illetve nem kommunista tisztektől, még akkor is, ha múltjuk egyetlen »fekete foltja« az volt, hogy korábban is hívatásos tisztek voltak", írta professzor dr. SZAKÁLY Sándor hadtörténész. ${ }^{1}$ NÉMETH Dezső ezredes az egyik tipikus példája volt ennek! Ráadásul — éppen egy kritikus időpontban — PÁLFFY György kedvelt munkatársaként tartották számon és talán ez is hozzájárult sorsának szomorú beteljesüléséhez.

NÉMETH Dezső ezredes 1913 VI. 30-án született polgári családban, a Szolnok-Doboka vármegyei Bethlen járás Bethlen nevü településén. Édesanyja WIESNER Franciska, édesapja NÉMETH Dezső ügyvéd volt. Főreáliskolát végzett, majd 1931-ben karpaszományosként bevonult a veszprémi 4/III. zászlóaljhoz, ahol 1931. VIII. 20. és 1932. X. 1. között karpaszományos honvéd, őrvezető, tizedes és örmesteri rendfokozatokat ért el.

1932. X. 1-én felvételt nyert a Ludovika Akadémiára, melyet 1935. VIII. 20-án főhadnagyi rendfokozattal végez el.

Tiszti pályáját Tata-tóvárosban a gyalogságnál kezdte meg, ahol 1935. VIII. 20-tól 1937. IX. 1-ig a 3/II. gyalog zászlóaljnál szakasz- és század-parancsnok, majd 1937. IX. 1-től 1938. I. 1-éig zászlóalj segédtisztként szolgált Veszprémben a 3/III. zászlóaljnál ${ }^{2}$.

1938. I. 5-től 1938. X. 1-éig a Honvéd Sporttanár és Vívómesterképző Intézetbe vezényelték, ahol sporttanári és vívómesteri képesítést szerzett. Ezt követően ismét visszakerült Veszprémbe, ahol 1938. X. 1-töl 1940. XII. 1-éig zászlóalj segédtiszt, majd géppuskás század-parancsnok volt a 3/III. zászlóaljnál.

1940. XII. 1-i hatállyal áthelyezték Aszódra, ahol egészen 1941. X. 1-éig az 1. tábori tüzérosztálynál 1/2. üteg-parancsnoki beosztásba került. 1941. X. 1-vel beiskolázzák a budapesti Hadiakadémiára, melyet 1943. X. 1-én végezte el.

A Hadiakadémián töltött éveit ne szokványos iskolaként képzeljük el, mert úgynevezett „tanulmányutakat” szerveztek a hallgatók számára a fronton harcoló alakulatok valamelyikéhez, harci tapasztalatok szerzése céljából! Így került NÉMETH Dezső hallgató 1942. IV. 20. és 1942. XI. 15. között az Urivnál ${ }^{3}$ harcoló magyar alakulatok 23/6. puskás századához század-parancsnoki, majd a Sztorozsevoje ${ }^{4}$ település mellett harcoló 46/I. zászlóalj parancsnoki beosztásába.

1943. XI. 1-vel került kinevezésre beosztott vezérkari tisztként a 25. Gyalog Ezredhez Désre, ahol mindössze három hónapot szolgált és 1944. I. 1-i hatállyal áthelyezésre került beosztott vezérkari tisztként a Honvédség Gyalogsági Felügyelőségére. 1944. III. 25-én kinevezték a Székely Határvadász Parancsnokság 1.a. (hadmüveleti) osztály vezetőjének Marosvásárhelyre. 1944. IV. 25-től 1944. XI. 20-ig anyagi vezérkari tiszt volt a VI. hadtest parancsnokságán (Worochta ${ }^{5}$, illetve Aknaszlatina ${ }^{6}$ ), majd 1944. XI. 20-tól 1945. II. 7-ig beosztott vezérkari tisztként szolgált az I. hadtestparancsnokságán, Budapesten.

1945. II. 8-án beosztottaival együtt a németek letartóztatták, de szovjet segítséggel kitörtek és a 3. gárdahadtest alakulataival harcolt a németek ellen. A harcokban február 16-án megsebesült. A változatosság kedvéért a szovjetek tartóztatták le és a Baján létesített hadifogolytáborba került, ahonnan 1945. VIII. 2-án szabadult. Már másnap, augusztus 3-án jelentkezett szolgálattételre.

Kezdetben a Honvédelmi Minisztérium Anyagi Csoportfőnökség, (1946 februárjától Anyagi Főcsoportfőnökség) Gépkocsi és Üzemanyag osztályára kerül először vezérkari őrnagy, anyagi csoportfőnökségi előadó, majd osztályvezető helyettes, illetve osztályvezető beosztásba. 1945. XI. 5én jutalomból, „A demokratikus Magyarország érdekében, a Honvédségen belül kifejtett tevékenység elismeréseként" léptették elő alezredessé. ${ }^{7}$

1945. XI. 3-án az Igazoló Bizottság igazolta. ${ }^{8}$

1946. III. 15-vel új szakasz kezdődik NÉMETH Dezső vezérkari alezredes életében: a 40/1946 számú (III. 19.) HM háziparancsban felmentették a gépkocsi és üzemanyag osztályvezetői beosztásából és a 41/1946 számú (III. 20.) háziparancsban áthelyezték a Katonapolitikai Osztály személyi állományába, ahol a határügyi alosztály vezetőjévé nevezték ki. ${ }^{9}$ 
1947 májusától a határőrség vezérkari főnöke és július 1-vel előléptették ezredessé. 1948. IV. 4-én PÁLFFY György társaságában részt vett az 1848-as zászlók visszaadási ünnepségén ahol KURASZOV vezérezredes a szovjet kormány nevében átadta PÁlFFY Györgynek a háború során a Szovjetunióba került 1848-as honvédzászlókat.

Tevékenységét magas kitüntetésekkel ismerték el:

- 1947. V. 29.: Magyar Szabadság Érdemrend ezüst fokozata;

- 1948. II. 26.: Köztársasági Érdemrend Tiszti keresztje;

- 1948. III. 16.: Határvadász jelvény arany fokozat;

- 1948. IX. 8.: Engedélyezik részére a Szovjetuniótól kapott „Budapest bevételéért” kitüntetés viselését.

1948. V. 27-én áthelyezték a Honvédelmi Minisztérium állományába és PÁLFFY György javaslatára kinevezték a Magyar Népköztársaság Moszkvai Nagykövetségének katonai attaséjává. Látszólag szép karriert futott be idáig, annak ellenére, hogy ludovikás tisztként került be a „,demokratikus hadseregbe”.

Moszkvai katonai attaséként is megállta a helyét. A szovjet katonapolitikai célkitüzésekről, a Szovjet Hadsereg átalakításáról, a haderő különböző haderőnemeinél folytatott katonai és politikai kiképzésről, annak a magyar haderőnél hasznosítható tapasztalatairól, az egyes, korabeli technikai fejlesztésekről, illetve az ezeket a külvilág számára demonstráló haditechnikai bemutatókról hazaküldött jelentései legalábbis erről tanúskodnak. Az 1948. VII. 25-én, a szovjet légierő közelgő ünnepnapja tiszteletére tartott bemutatóról például ezt írta: „A bemutató a védelem jegyében zajló politikai demonstráció volt, amivel azt akarták a szovjetek hangsúlyozni, hogy nem az amerikai népet akarják megsemmisíteni, hanem a védekező fegyverek (reaktív vadászgépek) segítségével a felhasználás előtt, a levegőben az atombombát szállító repülőgépeket."10

Jó érzékkel látta meg: nem biztos, hogy minden jelentése eljut a döntéshozókhoz, ezért az egyikben ezt jelentette: „Fontosnak tartom, hogy jelentéseim teljes egészében és szó szerint kerüljenek PÁLFFY altábornagy bajtárshoz. Ebben a jelentésben és a következökben is olyan átfogó katonai benyomásokat jelentek, amelyek elsősorban vezérkari képzettségü tiszt által értékelhetők helyesen"11

Több jelentésében foglalkozott a Szovjetunió katonai tanintézeteiben tanuló magyar hallgatókkal. Az egyikben például sorra vette az egyes akadémiákon (Frunze Lövész Akadémia, Sztálin Páncélos Akadémia, Leningrádi Tüzér Akadémia, Szolnyicsnogorszki fötiszti tanfolyam, stb.) tanuló magyar csoportokat és részletes jellemzést adott az egyes csoportok hallgatóinak felkészültségéről, a képzésben elért eredményeiröl, a csoportokon belül uralkodó viszonyokról és a szovjet fél által biztosított élet- és munkakörülményekröl, illetve javaslatokat tett a kiküldendő személyek körültekintőbb kiválasztását illetően. ${ }^{12}$

Szinte valamennyi jelentésének állandó témája voltak azok a szovjet katonai folyóiratok, kiadványok és tankönyvek, amelyeket megítélése szerint a magyar hadsereg kiképzésében is eredményesen lehetett volna hasznosítani. ${ }^{13} \mathrm{Az}$ ezzel kapcsolatos jelentéseihez minden esetben csatolta a hazaküldendő folyóiratok és könyvek jegyzékét is.

Több jelentésében is jelzte az attaséhivatal személyi és tárgyi feltételeinek hiányosságait. Nagyon hiányzott a nyilvántartást, a postázást és a pénzügyeket kezelö személy, aki levehette volna a válláról az adminisztratív terhek nagy részét, így több ideje jutott volna az érdemi munkára. Kezdetben még helyettest is kért, de később már azt írta: „már megelégednék egy polgári tisztviselővel, vagy tiszthelyettessel is, aki a pénztári naplók vezetését, az iktatást, postázást végezné." ${ }^{14}$ Ugyancsak komoly gondot jelentett a lakásával és az attasé hivatal irodai elhelyezésével kapcsolatos huzavona is. Alig több mint egy éves moszkvai szolgálata alatt három címről is küldött jelentést!

Nagyon fontosnak tartotta az otthonról kapott értékeléseket és visszajelzéseket. Erről így írt: „Szükségem lenne arra is, hogy jelentésem kiértékelését, illetve az ezzel kapcsolatos véleményt a rákövetkezö futárral megkapjam. ... nekem elsősorban és mindig azokkal a dolgokkal kell foglalkoznom, amelyek odahaza a konkrét munkához éppen és égetően szükségesek" 15

Valamennyi jelentésében részletes tájékoztatást adott a vizsgált időszakban a Moszkvába akkreditált katonai attasékkal, valamint a fogadó ország katonai képviselőivel létesített és fenntartott kapcsolatairól. Egy közülük külön is figyelmet érdemel: VALENCUELLA százados, argentin katonai attasé a nála tett búcsúlátogatása alkalmával közölte, hogy hazafelé európai körutazást tesz, amelynek során Magyarországot is útba ejti. NÉMETH ezredes az erről szóló jelentésében hozzátette: „Nyomatékosan felhívom rá az Elhárító Csoportfőnökség figyelmét!”16

Jelentéseiben több alkalommal is tájékoztatást adott a magyar nagykövetségen belüli viszonyokról, a nagykövet, a civil diplomaták és az attasé kapcsolatáról. Az általában pozitív 
hangvételü jelentések mellett szép számmal akadtak meglehetősen kritikus hangvételüek is, így például az, amelyik MOLNÁR Erik nagykövet megbízólevelének átadásáról készült: „Bántó a rendnek a hiánya! Eddigi megfigyelésem szerint a bolgár és a román követségen beosztott válogatott munkás elemek a fogadásokon sokkal méltóságteljesebben, természetesebben és nyugodtabban viselkednek, mint a polgári intellektuelekböl toborzott tisztviselöink!"”17

Az állomáshelyéröl küldött utolsó jelentése 1949. VIII. 3-i keltezésủ. 1949. VIII. 5-én hazarendelték és az ÁVH örizetbe vette. A PÁLFFY György ellen indított koncepciós per III. rendü vádlottjaként, a perirat szerint „folytatólagosan elkövetett hütlenség büntette és a magyar állam nemzetközi érdeke veszélyeztetésének büntette" címen, koholt vádak alapján 1949. X. 10-én halálra ítélték ${ }^{18}$, és október 24-én kivégezték. Az ítélet indoklásában többek között ez állt: „1946 őszétől 1948 májusáig rendszeresen közölt a határőrség szervezetére és elhelyezésére vonatkozó, szigorúan titkos és bizalmasan kezelendő adatokat, főként a jugoszláv határsávban elhelyezett honvéd alakulatok adatait, létszámát, fegyverzetét, az egyes határvadász zászlóaljak és századok adatait, állomáshelyét, a parancsnokok neveit és politikai jellemzését" "A A bíróság szerint ezzel követte el „folytatólagosan” a hütlenség büntettét. A magyar állam érdeke veszélyeztetésének büntettét pedig azzal valósította meg a vádirat szerint, hogy moszkvai attaséként vállalkozott a Jugoszlávia részére végzendő hírszerzői tevékenység folytatására, csak most már a Szovjet Hadseregről jelentett adatokat.

Különösen érdekes ennek a vádpontnak az indoklásában szereplő alábbi mondat: , Németh Dezső vezérkari ezredes, mint régi soviniszta, fasiszta tiszt került vissza a demokratikus hadseregbe. Pálffyval megállapították egymásról, hogy hasonló a felfogásuk és ennek eredményeként 1946 őszén a Határvadász Parancsnokság vezérkari főnöke lett. ... Pálffytól kapta utasításba, hogy Mrázovics volt budapesti, akkori moszkvai jugoszláv követ lesz a kapcsolata."20

1955. XI. 30-án a Katonai Felsőbíróság NÉMETH Dezső ezredest az ellene emelt vádak alól büncselekmény hiányában felmentette. A felmentő ítéletben szó szerint ez áll:

„Németh Dezső ezredes sem Magyarországon, sem pedig moszkvai tartózkodása alatt nem végzett hírszerzői tevékenységet Jugoszlávia számára, ezért a Bíróság az ellene emelt vádak alól bűncselekmény hiánya miatt felmenti. Ledényi Ferenc hadbíró ezredes, a Legfelsőbb Bíróság Katonai Kollégiumának elnöke, a Tanács elnöke., Kristóf István ezredes, ülnök, Matusek Tivadar örnagy, ülnök ". ${ }^{21}$

NÉMETH Dezső vezérkari ezredes polgári családból származott. Feleségével, BOTKA Jolánnal (született: 1916. V. 25.) 1940. XI. 6-án kötött házasságot. Érdekes ezzel kapcsolatban a személyi anyaggyüjtöjében található „Anyakönyvi lapon” olvasható megjegyzés: „Utólag tudomásul vettem a BOTKA Jolánnal 1940. XI. 6-án kötött házasságát!” (1948. V. 3-án: Személyügyi szerv, olvashatatlan aláirás) ${ }^{22}$ Férje kivégzését követően feleségét 1949 novemberében Budapestről kitelepítették Szolnokra, majd 1954-ben engedélyezték a visszaköltözését Budapestre. 1954-ben házasságot kötött RIBA János müszaki tisztviselővel, akitől 1962-ben elvált. Férje rehabilitálása után részére 120000 Forint kártérítést és két szoba összkomfortos lakást biztosítottak, valamint 1200 Forint kivételes nyugdíjat és gyermeke után 600 Forint árvaellátást állapítottak meg. 1986. VI. 1-től 4000 Forintot ítélt meg részére „nemzetgondozotti ellátás” címén a Minisztertanács Kivételes Ellátások Bizottsága. A Honvédelmi Minisztérium két alkalommal belföldön, egy alkalommal külföldön biztosított részükre térítésmentes üdülést. (A sors fintora, hogy éppen Jugoszláviában!)

Leányuk, Judit 1947-ben született, gimnáziumban érettségizett és 1966-ban férjhez ment egy fogorvoshoz.

A családot ellátták katonai egészségügyi igényjogosultsági lappal, a Magyar Néphadsereg Központi Klubjába belépésre jogosító belépővel, illetve 1963-ban a Honvédelmi Minisztérium híradó főnök közbenjárására lakásába vezetékes telefont vezettek be. A feleség 1963-ban kérelemmel fordult CZINEGE Lajos honvédelmi miniszterhez, hogy a férje Moszkvából történt hazarendelése alkalmából kint maradt értéktárgyaikat (szőnyegek, képek, dísztárgyak) segítsen visszajuttatni. ${ }^{23}$ A feladatot KISS Lajos ezredes akkori moszkvai katonai attasé kapta, akinek segítségével néhány, még előtalálható és azonosítható tárgyat visszakapott, a többi a feledés homályába veszett!

NÉMETH Dezső ezredes sírja a Farkasréti temető 30/2. parcellájában található (1. sor, 90. sírhely). 


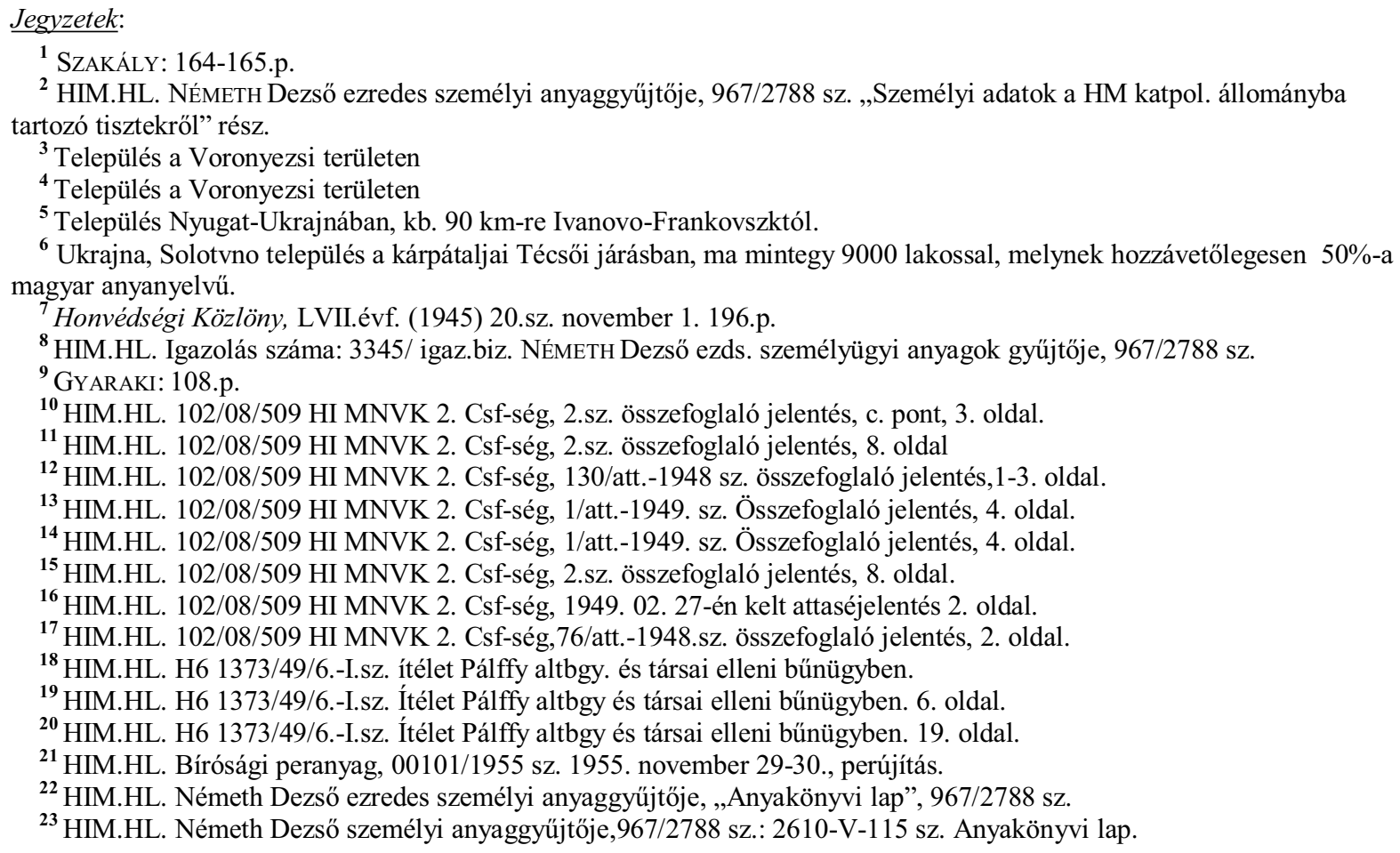

Jegyzetekben alkalmazott röviditések:

\section{MONOGRÁFIÁK ÉS KISMONOGRÁFIÁK}

SZAKÁLY

SzAKÁLY Sándor: Hadsereg, politika, társadalom, válogatott írások. Budapest, 1991, Lánchíd Kiadó. 170 p. HU-ISBN 9637497005.

\section{TANULMÁNYOK}

GYARAKI

- Gyaraki Károly: A katonai elhárítás történetéből. Hadtudomány, V.évf. (1995) 1.sz. 106-114.p. HU-ISSN 1215-4121.

\section{LEVÉL-, IRAT- ÉS DOKUMENTUMTÁRAK}

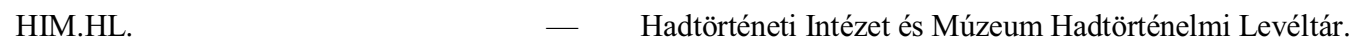

\section{Mellékletek jegyzéke:}

I.sz. melléklet.

A Katona Politikai Osztály szervezete 1946. VII. 1-től.

II.sz. melléklet.

Szervi utasítás a moszkvai katonai attasé számára. 
A Katona Politikai Osztály szervezete 1946. VII. 1-tól.

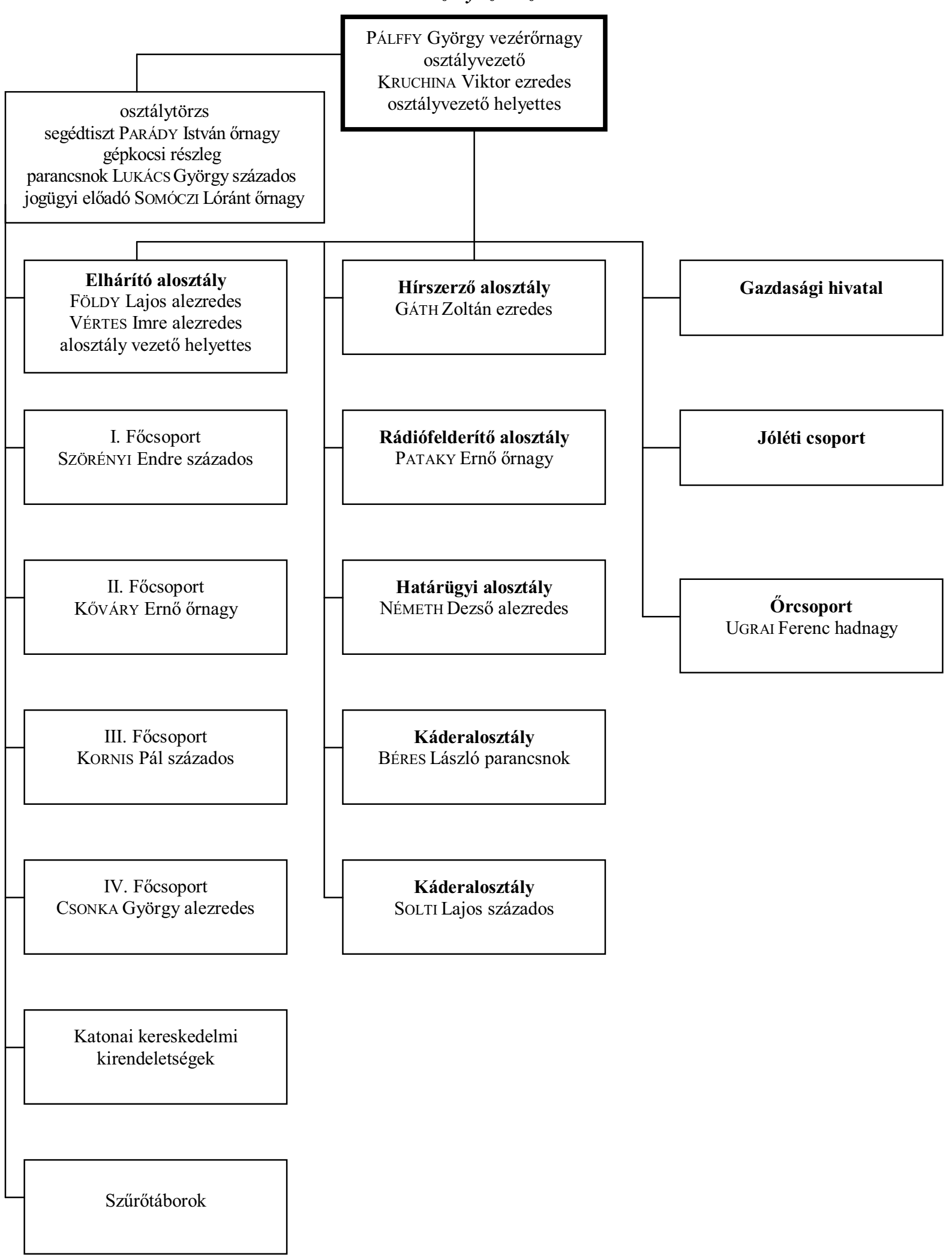

Forrás ! OкVÁtн Imre: Sziget egy reakciós tenger közepén. Adalékok a Katpol történetéhez 1945-1949. Államvédelem a Rákosi korszakban. 66.p. Budapest, 2000, Történeti Hivatal. 


\section{Szervi utasítás a moszkvai katonai attasé számára.}

$$
\text { II. sz. melléklet. }
$$

Szervi utasítás

A Magyar Köztársaság elnöke és a Magyar Kormány hozzájárulásával a Szovjet Unióban általam delegált magyar katonai attasé müködésére vonatkozóan az alábbiakban rendelkezem:

12 Feladat:

a, A katonai attasé képviseli minden tekintetben a Szovjet Unióban a magyar demokratikus honvédséget.

b, Tájékoztatja a szövetséges Szovjet Hadsereg Vezetőségét a magyar honvédség összes elvi és gyakorlati kérdéséről.

c, Biztosítja az állandó összeköttetést a szövetséges Szovjet Hadsereg és a honvédség között.

d, A szovjet és a magyar haderők közötti szövetséges viszonyból származó áruküldés rajta keresztül történik, ha más intézkedés nincs.

e, A szovjet haderő vezetőségének tudtával és beleegyezésével gyüjti mindazokat az elméleti és gyakorlati tapasztalatokat, amelyek a honvédség fejlesztésében szükségesek. A gyüjtött anyagot továbbítja a honvédség vezetőinek. Köteles a gyüjtött tapasztalati anyagot saját maga is kiértékelni, és kiértékelését az anyaggal együtt a honvédség vezetőinek továbbítani.

f, Minden lehetőséget felhasználva tovább mélyíti a két haderő közötti bajtársi és szövetségesi viszonyt.

g, Magasabb parancsnoki jogkörrel felruházott elöljárója a Szovjet Unióban tartózkodó összes honvédségi személynek.

2. Jogállás:

a, A magyar katonai attasé a Honvédelmi Miniszter közvetlen összekötő közege a Szovjet Hadsereg Vezetőségéhez.

b, A magyar katonai attasé, mint a Honvédelmi Miniszter közvetlen összekötő közege, a mindenkori Szovjet Unióbeli magyar nagykövetnek csak személyében, és e téren is csak fegyelmi tekintetben van alárendelve.

c, A magyar nagykövet/követ/ a katonai attaséval csak a követség szükséges személyzetére kiterjedő reprezentációs események alkalmával rendelkezik.

d, A katonai attasé személyzete ugyanolyan tekintetben van a magyar nagykövetnek /követnek/ alárendelve, mint a katonai attasé, és csak a katonai attasé személyén keresztül.

1. Összeköttetés:

a, A magyar katonai attasé a HM Katpol. Csoportfönökségén keresztül van a Honvédelmi Miniszternek alárendelve.

b, Utasításokat csak a HM Katpol. Csoportfönökségén keresztül kaphat és jelentéseit csak a HM Katpol. Csoportfönökségén keresztül terjesztheti fel.

c, A katonai attasé elvileg külön honvédségi futár útján tartja fenn az összeköttetést a Honvédelmi Minisztériummal, és a nagykövet /követ/ engedélyével igénybe veheti a Magyar Külügyminisztérium futárjáratait is. A nagykövet /követ/ viszont a katonai attasé hozzájárulásával igénybe veheti a katonai attasé futárjáratát.

d, A katonai attasé az illetékes szovjet hatóságok jóváhagyásával önálló rádióösszeköttetést is létesíthet a HM Katpol. Csoportfönökségével és önállóan rejtjelezheti táviratait.

e, A katonai attasé azonban a nagykövet /követ/ engedélyével felhasználhatja a nagykövetség/követség/ valamennyi müködő híradó eszközét is. A nagykövet /követ/ a katonai attasé hozzájárulásával viszont ugyancsak igénybe veheti a katonai attasé külön híradó eszközeit.

\section{Személyzet:}

A katonai attasé személyzetének létszámát, beosztását és magának a személyzetnek a személy szerinti kiválasztását a szükséghez mérten, az illetékes szovjet hatóságnak a hozzájárulásával, a HM Katpol. Csoportfönökség a katonai attaséval egyetértésben határozza meg.

3. Anyagiak:

a, A katonai attasé és személyzetének összes költségét közvetlenül a Honvédelmi Minisztérium fedezi.

b, Az anyagi ellátás (illetmények, berendezések, felszerelés, járművek, stb.) mértékét a katonai attasé javaslata alapján a HM

Katpol. Csoportfönökség a HM Anyagi-technikai Csoportfönökségével egyetértésben állapítja meg, illetve ezek alapján a HM javasolja a döntésre hivatott hatóságnak.

Budapest, 1948. május 12-én

Veres Péter sk.

Forrás ! Hadtörténeti Intézet és Múzeum Hadtörténelmi Levéltár.131/7/82 MNVK 2. Csf-ség. 13. jegyzet, 6. csomag, 102/08/516 Moszkvai attasé okmányai. 